\title{
Varför forska om fornisländska i 2000-talets Sverige?
}

\section{Av Karl G. Johansson, universitetslektor i nordiska språk}

\author{
Länk till presentation av Karl G. Johansson
}

I Värnamo visades i sommar en utställning om vandalerna, ett germanskt folk som fått ett enligt somliga oförtjänt eftermäle vilket främst framkommer i ord som vandal, vandalisera och vandalism. Jag hade inte själv möjlighet att se denna utställning, men från bekanta som sett den har jag förstått att den var väl värd ett besök. I en understreckare i Svenska Dagbladet den 7 oktober kritiserar Dick Harrison, historiker från Lund, känd för sina många böcker om olika aspekter på europeisk medeltid, den publikation som utkom i samband med utställningen i Värnamo. Dick Harrison är märkbart irriterad över de ideer om vandalernas ursprung och historia som framförs i katalogen av Pontus Hultén och Marie-Louise von Plessen. Han påpekar att vi i själva verket inte vet särskilt mycket om vandalernas äldsta ursprung, som i katalogen förs till Småland, och deras öden efter att deras rike i Nordafrika ödelagts av en östromersk här år 534, som av katalogförfattarna förläggs till området runt Östersjön där områdesnamn somVendel och Vendsyssel anses vittna om deras närvaro under Vendeltiden. Varför blir nu Dick Harrison så förargad över detta? Ett citat från understreckaren kan nog ge en förklaring, och dessutom leda oss in på det som den här artikeln skall handla om. Han skriver:

\footnotetext{
Vadan denna min upprördhet? Varför ondgör jag mig över en av vårt lands mest respekterade museiprofiler i modern tid? Svaret är att jag ser ett spöke vandra genom boken, och det är Olof Rudbecks spöke, den gammalsvenska göticismens spöke, en tjutande gast från fordom som ånyo iklätt sig ett blodfärgat lakan med rostiga kedjor. Den "sanna historien" om vandalerna tycks sprungen ur ett svenskt bygderomatiskt förflutet som jag inbillade mig att vi lämnat bakom oss för länge sedan.
}

Denna konflikt mellan en yrkeshistoriker och utställningskatalogens författare relaterar direkt till flera områden där jag själv är verksam och kan därför utgöra en god startpunkt för en diskussion om meningen och relevansen för vår tid att studera de fornisländska texterna och deras språk. Olof Rudbeck utgör nämligen en slags höjdpunkt på den första svenska forskningsinsatsen på det fornisländska området, en höjdpunkt som de flesta av oss inte vill förknippas med i dag. Under 1600-talets svenska stormaktsperiod utvecklades i Stockholm och Uppsala en livlig forskning i gamla dokument och i arkeologiskt material, allt för att belägga en storslagen historia och ge legitimitet till Sveriges anspråk på att vara en ledande europeisk makt. Liknanden verksamhet finner vi i Danmark där det naturligtvis var Danmark som skulle lyftas fram. Den nationalism som går under benämningen göticism kom att under den här tiden utvecklas till en statsangelägenhet där kungamakten stod som högsta garant. Men här börjar även den långa forskningshistorien på området som vi själva, vare sig vi vill det eller ej, är en del av. Även om vi i dag tar avstånd från den ideologi som utgjorde incitamentet för 1600-talets forskning kan vi inte undgå det faktum att materialet i stor utsträckning insamlades och sorterades under den här perioden, och att en del grundläggande linjer i forskningen om materialet stammar härifrån. Dick Harrison trodde att Rudbecks spöke spelat ut sin roll, men så är tyvärr inte fallet. Det är inte bara i nynazistiska kretsar utan även i mer respektabla miljöer både inom och utanför universitetet många föreställningar i omlopp om goter och vikingar som härstammar från Rudbecks göticistiska spökslott utan att vi egentligen är medvetna om det. Det är därför viktigt att vi som humanister inte förskansar oss i universitetets glashus eller i vårt snäva ämnes avskildhet utan ständigt deltar i den offentliga debatten för att bemöta de värsta missförstånden och de farligaste chauvinistiska tendenserna i dagens sökande efter regional identitet i en allt mer global värld. Dick Harrisons understreckare, liksom hans vilja att i 
sina böcker sprida kunskap om medeltida historia, är goda exempel på hur humanister kan delta i debatten.

De forskningsområden som omedelbart kan ställas upp där forskning kring de fornisländska texterna är relevanta i förhållande till den i dag pågående diskussionen om globalt och lokalt har ofta en eller annan anknytning till 1600-talets göticistiska insamlings- och forskningsverksamhet. Inledningsvis är det naturligtvis denna verksamhet i sig själv som ger oss inblickar i hur vår bild av den fornisländska världen börjar formas, i ideologiska formuleringar men även i forskningsresultat och översättningar. Men dessutom kommer själva samlingarna som initierades av de göticistiska forskarna att vara intressanta. Dessa båda områden har under de senaste årtiondena varit svårt eftersatta i svensk forskning. Detta leder mig in på det tredje området som jag vill diskutera i dag, nämligen den moderna forskningen kring den fornisländska litteraturen. På dessa områden var Sverige en framstående forskningsnation under första hälften av 1900-talet, med åtskilliga framstående filologer med internationellt rykte. Men hur ser det ut i dag? Detta återkommer jag till efter en kort historisk översikt.

1664 utkom Götreks saga för första gången på svenska. Det var fornforskaren Olof Verelius som försvenskat den isländska fornaldarsagan, alltså en saga om ting som redan islänningarna under medeltiden betraktade som forntida. Verelius fortsatte redan efter två år med en översättning av ytterligare en äventyrlig saga, nämligen Bosa saga, som är lite fräck i sina historier och som av en norsk forskare nyligen har diskuterats i samband med Boccaccios Il Decamerone; namnet Bosa för tankarna till författarens namn Boccaccio. Ytterligare en fornaldarsaga översattes av Verelius. Det var Hervarar saga som utkom 1672. På titelbladet kan man läsa: "Hervarar saga på gammal götska med Olai Vereli uttolkning och notis". Här är begreppet gammal götska intressant; denna benämning på fornisländskan är nämligen central för göticisternas bruk av det fornisländska materialet. Hervarar saga var förvisso intressant ur ett svenskt perspektiv i det att den återgav en historia om föregivet svenska förhållanden i en fjärran urtid, men det var som källa till ett gammalt götiskt språk de isländska texterna kom att få stor betydelse. Förutom att introducera ättestupan i Sverige, en företeelse som fortfarande lever i varje bygd med självaktning där det finns ett högt stup att kasta sina gamla och orkeslösa samhällsmedborgare från, introducerar Verelius i sin översättning av sagan ett antal ord i svenskan som är direkt hämtade i källtexten. Som exempel kan nämnas ett ord som idrott som här förekommer för första gången i en nysvensk text. Nåväl, det skall erkännas att svenskan fortfarande inte nått sin fulla status i Verelius arbete. Trots de språkpolitiska idéer som kom att bli så viktiga för stormaktstidens göticism, kanske främst företrädda av Georg Stiernhielm, var det latinet som var Verelius vetenskapliga språk. När han skall kommentera sagan gör han det självklart på latin.

Snart kom emellertid andra fornisländska texter i sökljuset för de götiska fornforskarna. Redan 1670 utkom den så kallade Norlandz Chrönika och Beskriffning, en översättning av Snorre Sturlassons Heimskringla utförd av islänningen Jonas Rugmann, från trycket hos Johann Kankel på Visingsö. Rugmann var på väg till Köpenhamn för att fortsätta sina studier där, när hans skepp tvingades in till svensk hamn. Han kom snabbt i tjänst hos Per Brahe på Visingsö och kom, liksom flera andra islänningar som kom till Stockholm och Uppsala under 1600-talets andra hälft, att spela en viktig roll för de svenska fornforskarna. Utan hjälp från språkkunniga islänningar hade arbetet med att översätta och kommentera det isländska materialet naturligtvis blivit betydligt svårare. Rugmanns översättning av Snorres berättelser om de nordiska fornkungarnas liv kom sannolikt att ytterligare öka intresset för de isländska handskrifterna. Här kunde ju ett storslaget förflutet beläggas i de gamla "götiska" skrifterna. Bara några decennier senare utkommer Snorres verk ännu en gång på svenska. Den här gången är det en av tidens stora personligheter, Johan Peringschiöld, som står för översättningen. Parallellt med den svenska översättningen utges nu den isländska texten och dessutom en latinsk översättning. Detta stora arbete utkommer under åren 1697- 1700 och utgör väl monumentalverket för den svenska göticismen vid sidan av Olof Rudbecks Atlantica. Efter dessa stora insatser minskar intresset för de göticistiska ideerna. Sverige förlorar under de följande decennierna sin position som 
europeisk stormakt, och de efterföljare till Rudbeck och Peringschiöld som finns, personer som Eric Julius Biörner och Johan Göransson, betraktades redan av många i sin samtid som kufar. Därmed inte sagt att de götiska idéerna försvinner. Även en skribent som Olof Dalin bygger vidare på det chauvinistiska verket i sin svenska historia. Det är de mer explicit uttalade formerna för göticism som nu nedtonas. En nytändning får göticismen inte förrän under första hälften av 1800-talet, när författare som Erik Gustaf Geijer och Esaias Tegnér tar upp de götiska ideerna i sin diktning. Här dyker den berömda ättestupan åter upp i poesin, t.ex. På Hallebergs stupa från 1815 av poeten Vitalis:

Här stod mannen uti forna dagar med föragt för lifvet och dess flärd och till trotts utaf Naturens lagar hängick dristigt till en annan verld

Exemplen på hur nordisk manlighet i forntiden i kontrast till en förvekligad samtid när en förödande slavmentalitet vunnit insteg kunde bli många från den här tiden. Romantikens göticism bygger alltså vidare på stormaktstidens bild av vikingen som en manlig förebild och den forntida historien som exempel på en germansk storhetstid när män var män. Denna bild har kanske bleknat i sentida forskning, men dessförinnan var den som vi vet en viktig beståndsdel i den nazistiska ideologin. Redan med generationen efter Verner von Heidenstam hade denna storvulna germanska ideologi spelat ut sin roll som inspirationskälla för svenska författare. Den förpassades med nazismens fall åtminstone tillfälligt till det bygderomantiska förflutna där Dick Harrison liksom jag själv anser att den hör hemma.

Men vart tog det göticistiska språkprogrammet vägen? Med de ovan nämnda Eric Julius Biörner och Johan Göransson marginaliserades de göticistiska strävandena efter att återetablera ett götiskt språk med utgångspunkt i fornisländska och fornsvenska källor. Men idén om svenska språket som modersmål hade definitivt etablerats även utanför de göticistiska kretsarna. Under 1700-talet utvecklas forskningen i det äldre språkmaterialet samtidigt som svenska språket diskuteras livligt av språkryktare. Mot slutet av seklet är språkvården väl etablerad och svenska betraktas som ett modernt språk. Svenska Akademien bildas som en språkvårdande institution och svenska språket blir en huvudangelägenhet för många humanister. Samtidigt vinner den jämförande språkvetenskapen insteg i universitetsvärlden. Engelsmannen William Jones har med ett föredrag om paralleller mellan de europeiska språken och det indiska sanskrit lagt grunden för studiet av de besläktade språk som kommit att kallas indoeuropeiska. I den framväxande jämförande språkvetenskapen spelar i Norden en dansk forskare, Rasmus Christian Rask, en avgörande roll. Han beskriver fornisländskans grammatik och sätter denna i relation till den indoeurpoeiska diskussionen, och dessutom lämnar han bidrag till beskrivningen av danskt, fornengelskt, samiskt och finskt språk som har haft stor betydelse för studiet av dessa. Rasmus Rask var ett barn av sin tid och kom med utgåvor av Snorres Edda och eddadiktningen att sätta ny fart på forskningen kring den fornisländska litteraturen och det fornisländska språket. Hans utgåvor låg även till grund för de göticistiskt präglade översättningar till svenska av fornisländska texter som utkom under 1800-talets första decennier och som kom att påverka romantiska poeter som Geijer och Tegnér.

Denna göticistiska och nationalromantiska tradition leder nu rakt in i den nordiska nationalromantiken under andra hälften av 1800-talet. I Norge börjar språkforskare samla in dialektmaterial och läraren Ivar Aasen skapar det som kommit att bli ett av de två norska skriftspråken, nynorsk. I alla de nordiska länderna utvecklar sig studiet av de egna språken och dessas historia till ett universitetsämne, Nordiska språk, som vid mitten av 1800-talet får sin första professur i Sverige. Under de närmaste hundra åren växer detta ämne ut till att omfatta många olika forskningsaspekter av svenska språket med anknytning till forskningen om de andra nordiska språken. En särställning i alla de nordiska länderna får det fornisländska materialet. Om man vill nå berömmelse inom ämnet ska man skriva något viktigt om fornisländskt språk. Under den här perioden är alltså Sverige en av de ledande 
nationerna i världen på det här området. Adolf Noreen skriver en historisk grammatik för fornisländskan som ännu i dag ligger till grund för alla som studerar detta språk, och forskare som Ernst Albin Kock och Sven B.F. Janson, Gustav Lindblad och Elias Wessén gör betydande insatser för utforskningen av det isländska materialet.

Här kan det vara värt att återvända till 1600-talet ett ögonblick. Det material jag talar om är de isländska skinnhandskrifter som bevarats från medeltiden och som innehåller islänningasagor, nordiska kungasagor, eddadiktning och mycket mer av intresse för forskarna. Den största samlingen av isländska handskrifter byggdes upp av islänningen Árni Magnússon under de första årtiondena av 1700-talet. Den har sedan dess förvarats vid Köpenhamns universitet där ett helt institut ägnats åt studiet av dem. Sedan 1971 har Danmark emellertid lämnat tillbaka åtskilliga handskrifter till Island där ett systerinstitut i dag har ansvaret för förvaring och forskning.

De svenska göticisterna var emellertid inte så mycket sämre på att samla in handskrifter. Dels sände man islänningar ut på handskriftsjakt på Island, dels köpte man in samlingar från Danmark, och därigenom skapades betydande samlingar av isländska medeltidsmanuskript vid universitetsbiblioteket i Uppsala och Kungliga biblioteket i Stockholm. När den nordistiska forskningen i det fornisländska materialet tog fart under 1800-talet fanns det alltså ett rikt material att förvalta i de svenska samlingarna. Forskare som Adolf Noreen och Sven B.F. Janson hade tillgång till material på hemmaplan som i mångt och mycket inte stod det dansk-isländska efter. Det var därför inte onaturligt att den svenska forskningen på området blev så betydande. Värderingen av fornisländskan kan illustreras av ett citat ur Elias Wesséns bok De nordiska språken. Wessén skriver:

\footnotetext{
Isländskan är under medeltiden Nordens ojämförligt viktigaste språk. Den är först och främst det ålderdomligaste av de nordiska litteraturspråken och därför av utomordentligt stor betydelse för förståelsen av deras ursprungliga förhållanden och deras utveckling. Isländskan kan i detta avseende i viss mån jämföras med latinet; den har för Nordens språk samma betydelse som latinet för förståelsen av franskan och de övriga romanska språken. (s. 34)
}

Under andra hälften av 1900-talet gick emellertid intresset för de fornisländska texterna stadigt ner i samma takt som språkhistoria och andra traditionella nordistikämnen vek undan för ett ökande intresse för lingvistik och modern svenska. Undervisningen i ämnet reducerades successivt under årtiondena från 1960 till 1980. När vi nått så långt fram i tiden är det egentligen bara enstaka studenter med specialintressen som lägger någon större vikt vid studiet av de fornisländska texterna. I grundutbildningen kan man som mest tala om orientering i ämnet. Detta syns alltså även i den svenska representationen inom den internationella forskningen på området. Sverige representeras i dag främst av historiker och litteraturvetare inom områden, där det isländska materialet studeras, medan filologer och språkhistoriker lyser mest med sin frånvaro.

Nu kan man fråga sig utifrån det sagda varför vi över huvud taget ska ha någon utbildning och forskning i det fornisländska materialet. Och här menar jag att min framställning kan leda till följande iakttagelser.

En viktig del av svensk historia, kulturhistoria och språkhistoria har utgångspunkter i 1600talets göticistiska forskning i det här materialet. För att vi seriöst ska kunna tränga in i den göticistiska tankevärlden krävs det att vi upprätthåller en kompetens inom nordisk filologi. Detta är i särskilt hög grad viktigt för studiet av periodens betydelse för den svenska språkidentitetens framväxt, för hur vi ser på vårt svenska språk. De linjer som utgår från 1600-talet har som vi kunde se utvecklats av våra största romantiska skalder och haft stor betydelse för vårt universitetsämnes utveckling. Här är det värt att tänka på hur många svensklärare som under de senaste etthundrafemtio åren har fått sin utbildning vid våra institutioner för nordiska språk.

Men vi har också en, eller kanske två sammanhängande, förpliktelser i det internationella forskningssamhället som vi i dag har svårt att leva upp till. Det första gäller hur vi förvaltar våra samlingar av fornisländska handskrifter om detta sätts i relation till omvärldens 
intresse. Under de senaste trettio åren har det kommit ut två doktorsavhandlingar om fornisländska handskrifter i Sverige. Den ena utkom 1974 och den senaste, min egen, 1997. Och detta från det land som har två av de största samlingarna av fornisländska handskrifter i världen. Sätts detta i samband med den andra punkten där vi kan sägas ha ett ansvar, nämligen att föra vidare den tradition av framstående forskning som Sverige kunde framvisa fram till för några decennier sedan är det väl egentligen skandalöst att vi inte upprätthåller kompetensen på detta område.

Hur är det nu till sist med språket i ett globalt och lokalt perspektiv? När vår nutid blir alltmer global blir det allt viktigare för oss med en förankring i det lokala eller regionala. Det kan därmed vara relevant att tala om språket inte enbart i ett nutidsperspektiv utan även i ett historiskt perspektiv. Vårt eget språk och de nordiska språken har ett förflutet som är en del av vår identitet. I tider när allt fler söker sin identitet i historien och traditionen blir det allt viktigare att förvalta och förmedla det vi vet om denna historia. Om vi inte gör detta på ett ansvarsfullt och seriöst sätt riskerar vi att samma historia åter hamnar i händerna på ytterlighetsgrupper som tar patent på sanningen, och att okunnigheten breder ut sig även inom forskningsdiscipliner vid våra universitet. Dick Harrisons irritation över behandlingen av vandalerna kan säkert även finna näring i arbeten som publiceras av universitetsforskare som i brist på kompetent utbildning på området vrider forskningens klocka tillbaka, inte bara till före nazismens misshandel av källmaterialet utan rentav helt till Olof Rudbeck.

(C) $\underline{\operatorname{Karl} G . \text { Johansson }}$ 